\title{
Journalistic Independence and Public Funds: Institutional Social Communication as a Distortion of Competition in the Information Market
}

\author{
Miguel Álvarez-Peralta \\ Castilla-La Mancha University
}

This research focuses on the scientific and journalistic controversies about the effects of the budget that the Spanish administration uses for institutional social communication through the media, as a potential distortion for fair competitiveness in the journalistic market. We expose the problem and then review the discourses about this phenomenon in both the academic literature and mainstream newspapers. When we compare the coverage made by traditional newspapers and the native digital media, we identify a lack of attention both in established mainstream journalism and in academic research, in contrast with the strong criticism within these recently created digital newspapers. This observation converges with the fact that the mainstream press receives much more funding from regional and national governments, becoming much more dependent on the administration.

Keywords: journalism, journalistic markets, institutional advertising, journalistic business models, media regulation, digital media

\section{INTRODUCTION: DEFINITION AND OBJECT OF STUDY}

Although limited to professional circles, controversies periodically arise in Spain regarding the partisan use of the budget for institutional communication via the media. The current legislation has tried to put an end to the "self-publicity" with which some governments have promoted their work with electoralist intentions. But beyond this illegitimate self-promotion with public funds, another less visible mechanism operates with similar partisan intention, regardless of the content of such advertising: the biased distribution of advertising to related media.

Judicial rulings, professional reports, civil society organizations and even European institutions periodically draw attention to this issue (Salaverría and Gómez Baceiredo 2018, p. 3; Gómez and Gómez 2017) and the Council for Transparency and Good Governance itself has indicated in its resolutions that the media plans of public institutions contain information "that must be made public ex officio, by mandate of article 8.1 a) of the Law on Transparency"1. In spite of this, accusations of non-compliance continue. The president of the press employers' organization Asociación Española de Editoriales de Publicaciones Periódicas (AEEPP) denounced this in the magazine of the Press Association of Madrid:

There is a specific issue that neither the media nor politicians nor citizens are talking about. (...) I am talking about institutional advertising in the private media. (...) No one has begun to add up the numbers, perhaps because they are largely opaque and dispersed (...) Some or perhaps many political leaders (...) put much more publicity for their institution in the 
related media, even though they are not entitled to such amounts by objective criteria of circulation, audiences or affinity of the public sought in each campaign. (...) We journalists who have been in the industry for many years at the management level know that these are not widespread practices, but unfortunately they are frequent. (Escolar 2014, p. 14)

Article 2 of Law 29/2005, of December 29, on Advertising and Institutional Communication (hereinafter LAIC) defines institutional advertising campaigns as "activities aimed at the dissemination of a common message or objective, addressed to a plurality of recipients, which use a paid or granted advertising medium and are promoted or contracted by one of the entities" of the state public sector. In its Art. 2.b), the law distinguishes this advertising from Institutional Communication campaigns, a category it defines by exclusion as those "that use forms of communication other than strictly advertising". In order to refer extensively to both activities, we will adopt here the definition of Institutional Social Communication (hereinafter ISC), usual in scientific literature (i.e. Rey et al. 2009, p. 1; Cuesta et al. 2011). It should be noted that there is no definitive terminology that defines the limits of ISC, distinguishing it from other more subtle or indirect forms that are equally aimed at promoting changes in attitudes, neither in the academic field, nor among the autonomous and state laws that regulate this activity (Cortés González 2008, p. 234; Pineda and Rey 2009, p. 22-23). As Pineda and Rey point out, beyond the normative proposals, any critical analysis must recognize the contradictory nature of ISC, which involves

a case of communication that is not necessarily propagandistic and that takes place under institutional conditions of propagandistic broadcasting. This is due to the peculiar nature of the State as an instance of power. The State implies simultaneously (a) a coercive structure and (b) a sphere of preservation and defense of general interests. (Pineda and Rey 2009, p. 30)

\section{STATE OF AFFAIRS}

The fact that the Institutional Social Communication of the administration exercises an enormous influence on the media market due to the injection of income that it supposes, is not by any means an unknown or novel phenomenon in the field of mass communication studies (i.e. Yarwood and Enis 1982, p. 43-44). Often the state is the first advertiser in Western countries. In Spain this is true even without adding up the amounts invested from autonomous communities and local entities (Pineda and Rey 2009, p. 12; Cortés González 2011, p. 3). Despite this, the scientific literature on ISC, in addition to being very limited, has prioritized other aspects in the treatment of this phenomenon, making its effect on free competition a taboo.

First of all, we notice that the bulk of the scientific literature on ISC in Spain is losing its relevance, becoming progressively obsolete due to the recent evolution of the political and economic framework. For the most part, although published at a later date, the studies refer to periods prior to the decline of the twoparty system and the emergence of new groups in the national political arena following the political and cultural impact of the 15M Movement (Feliu-Albaladejo 2009; Canel and Sanders 2010; Gálvez Muñoz 2011; Feliu-Albaladejo 2011; Cortés González 2011; Fernández Poyatos and Feliu García 2012; Urbina Fonturbel 2012; García Llorente 2015; Martínez Pastor 2016). This implies that very few works can account for the evolution of journalistic discourse, the state of affairs, recent jurisprudence or the latest reforms of the legal framework at a national and a regional level.

Much of the published literature focuses on the conceptualization of this type of communication on a theoretical level and the discussion of its limits or its deontology (Alameda García and Fernández Blanco 2002; Cortés González 2008a; Pineda and Rey 2009; Collantes 2009). There is also a remarkable number of researches focused on analyzing the contents of ISC (Ramos Serrano, Garrido Lora and Rodríguez Centeno 2009; García López 2012), as well as its discursive, rhetorical and semio-narrative qualities (Gómez and Aubia 2009; Ruiz Collantes et al. 2009; Urbina Fonturbel 2012; Segura-García 2017), including its implicit content aimed at promoting partisan positions in a covert way (Guerrero Serón 2009). 
Some studies attempt to typify the ISC sub-genres and then trace variations according to the governing party (i.e. Cortés González 2011). Even the studies most openly critical of the partisan use of ISC have tended to focus on its hidden agenda of ideological persuasion (i.e. García López 2001; Rey et al. 2009) rather than on structural economic aspects.

Among those who do adopt a structural perspective, it is common to include the issue as part of a broader economic phenomenon, such as the set of subsidies to the press (Fernández Alonso and Blasco Gil 2014), the effects of the crisis on the media system (Fernández Alonso, Guimerà i Orts and Fernández Viso 2012; Díaz-Nosty 2011, p. 28) or the boost of different economic sectors depending on the different regional governments (Feliu García and Feliu Albaladejo 2016), recognizing their impact on the media market but without focusing on the distortion that their arbitrary and opaque distribution may represent, or in any case mentioning it in a superficial way (Álvarez-Peralta 2014, p. 61-62).

Most of the research in our country has focused on case studies from discursive perspectives, referring to the usual topics in ISC (health, road safety, violence against women, etc.) and examining the ISC of a particular public institution (Martínez Pastor and Vizcaíno-Laorga 2008; Papí-Gálvez and Orbea Mira 2015; Segura-García 2015, 2017 ; Rodríguez López and Robles Álvarez 2016). As for its territorial scale, it is easier to find studies that analyze the ISC of some autonomous administration than that of the state level, probably because they offer a more comprehensive corpus (Feliu García and Feliu Albaladejo 2011; Feliu Albaladejo and Feliu García 2012; Fernández Poyatos and Feliu García 2012).

In conclusion, we agree with Cortés González $(2011$, p. 3) when he points out that unlike corporate communication, political propaganda or commercial advertising, ISC "is an object of study that is still largely unworked despite its enormous importance and the wealth of perspectives from which we can approach it", so that "the little literature we find on the subject is not well understood". In particular, there is a clear need for studies that specifically address the controversies on the impact of ISC as a distortion of the dynamics of the information market.

\section{HYPOTHESIS AND METHODOLOGY}

Based on the mentioned complaints, the bibliographic review and the analysis of the official data ${ }^{2}$, our study was based on the following hypotheses:

- There are strong differences in the frequency and quality of news coverage on this phenomenon between the traditional paper press and the new digital press, producing, in the former, a deficit of attention and a framing of the news that systematically leads the attention to focuses of interest different from the market distortion.

- There is also a lack of academic research in Spain on the signs and complaints of opaque and biased distribution of the ISC budget and its effects on the media market.

To contrast the first hypothesis, in addition to the review of the scientific literature (in which the second one has been confirmed), we will resort to the analysis of the journalistic content applying lexicometric techniques of CATA (Computer Assisted Text Analysis) to study a corpus composed of the complete digital editions of four national newspapers. The sample includes the two main references as a national non-free paper press, El País and El Mundo, and two recently created national digital newspapers: eldiario.es and infolibre.es. Likewise, we will analyze official documentary sources such as the Government's reports on investment in Advertising and Institutional Communication and those of the Framework Agreement for the provision of services for the purchase of space in the media and other supports for the diffusion of institutional advertising campaigns (AM 50-2017).

\section{RECENT DEVELOPMENTS OF ISC IN FIGURES}

The State budget for ISC grew from the end of the seventies, when it began to constitute specific items, until the end of the nineties, when it stabilized around 170 million euros (Cortés González 2011, p. 13-19). Coinciding with the 2004 general elections, the Popular Party Government increased that budget by $31.7 \%$, to 224 million Euros. The items have been varying according to the changes in the ministerial organization 
chart of the last decades, but always maintaining the constant of giving a growing weight to commercial advertising (not regulated by the LAIC) as opposed to non-commercial advertising (regulated in the aforementioned law). During the second legislature of Zapatero's government the budget was reduced by half due to the economic crisis. As of 2006, when the LAIC came into force, we have systematic data on investment plans and the budget executed, which allows us to conclude the following trends in its evolution:

- Strong decline in non-commercial institutional campaigns both in number and budget since 2009 despite the slight recovery in the 2013-2015 period.

- Increasing "digitalization" of investment, which is allocating more resources to network campaigns and less to analog media. By 2018, the General State Administration is already planning more campaigns on the Internet (62) than on television (36), press (49) or radio (44).

- Radio has seen its volume of investment reduced to a lesser extent than television or the written press, although in terms of the amount of funds allocated, the primary media continues to be television.

- Both in number of campaigns, and in planned and finally executed budget, the trend fall in the last decade of institutional campaigns (subject to the LAIC) is much higher than in commercial ones (which sell some product such as State Bonds or Lottery, not subject to the legal restrictions of the LAIC). The budget for the second type of campaigns was only cut until 2012, it experienced a greater recovery in 2013-2015, and the number of campaigns has grown steadily at all times, unlike non-commercial ones.

Charts 1 and 2 respectively summarize the evolution of planned and executed spending in ISC over the last decade (there was no budget in 2016).

\section{FIGURE 1 \\ EVOLUTION OF BUDGETS IN PLANNED AND EXECUTED (RESPECTIVELY) ISC BY THE GENERAL STATE ADMINISTRATION IN THE LAST DECADE}

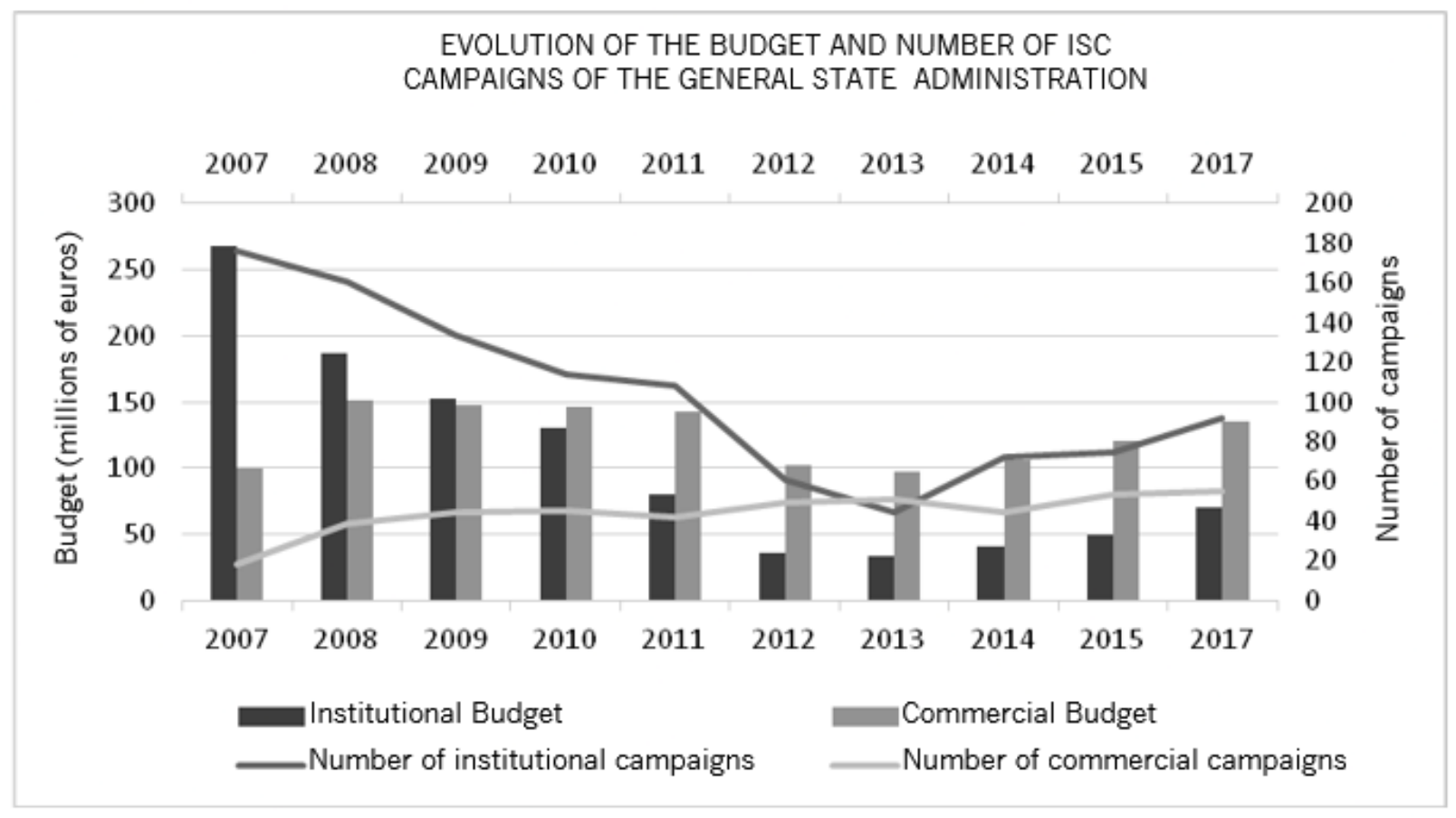

Source: own elaboration

Data source: General State Administration 
FIGURE 2

\section{EVOLUTION OF BUDGETS IN PLANNED AND EXECUTED (RESPECTIVELY) ISC BY THE GENERAL STATE ADMINISTRATION IN THE LAST DECADE}

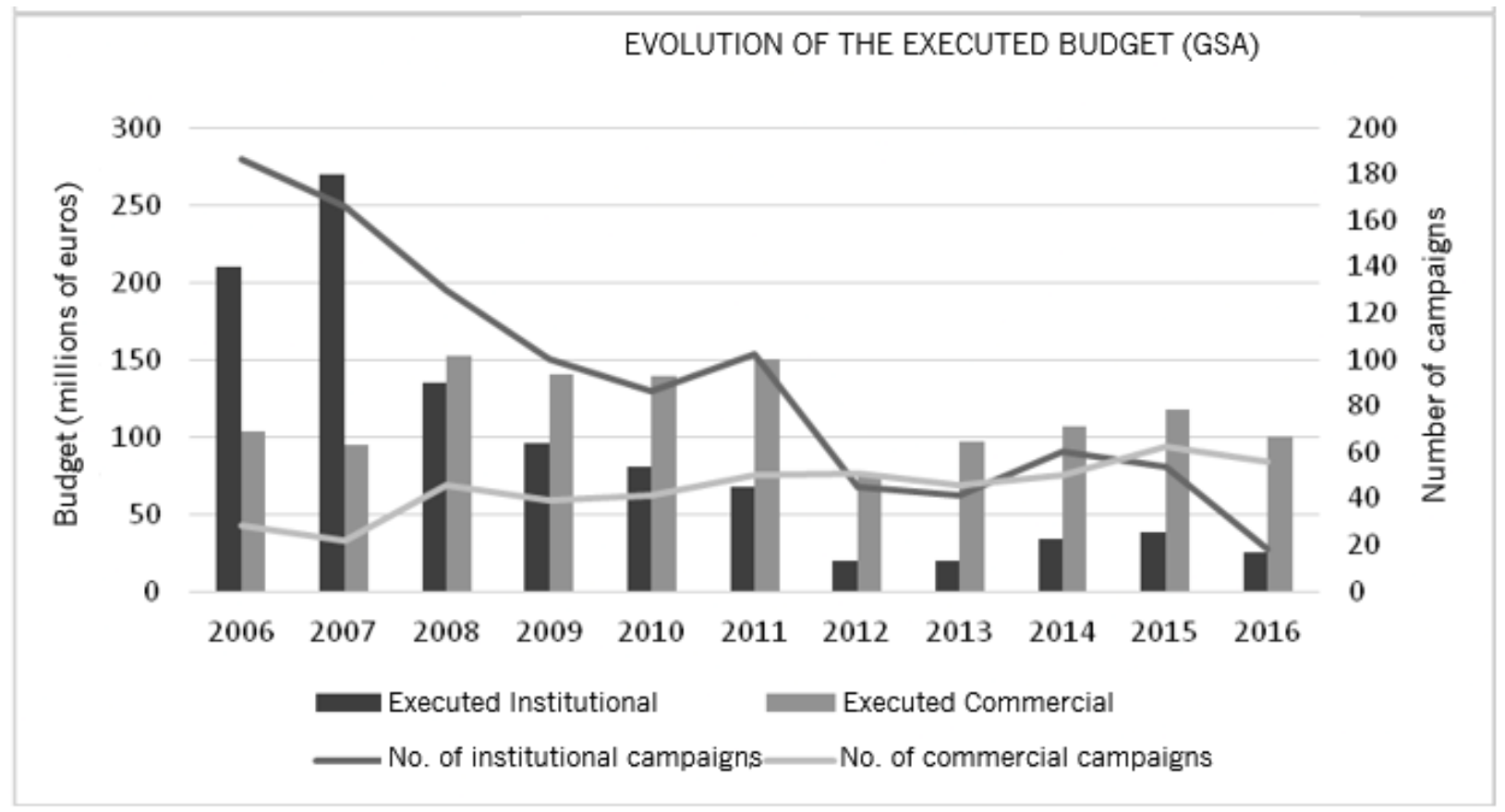

Source: own elaboration

Data source: General State Administration

\section{INFORMATION COVERAGE ON INSTITUTIONAL ADVERTISING}

If we adopt the Google Trends ${ }^{4}$ tool as the first indicator of the interest of Internet users in an issue, and therefore of its presence in the digital public sphere, we observe three macro-phenomena in the recent evolution of interest in "institutional advertising", the most common term in the press (cf. Chart 3): 1) the trend in the evolution of searches related to this term has been decreasing in the last decade and has stabilized in the last five years, well below previous periods; 2) the time when most searches take place is between March and July 2005, coinciding with the first debates on a new Law on Advertising and Institutional Communication; 3) there is a rebound in March and April 2007, when the law on institutional advertising in Andalusia was approved. 
FIGURE 3

SEARCHES MADE IN GOOGLE FROM SPAIN ON "INSTITUTIONAL ADVERTISING"

(2004-2018)

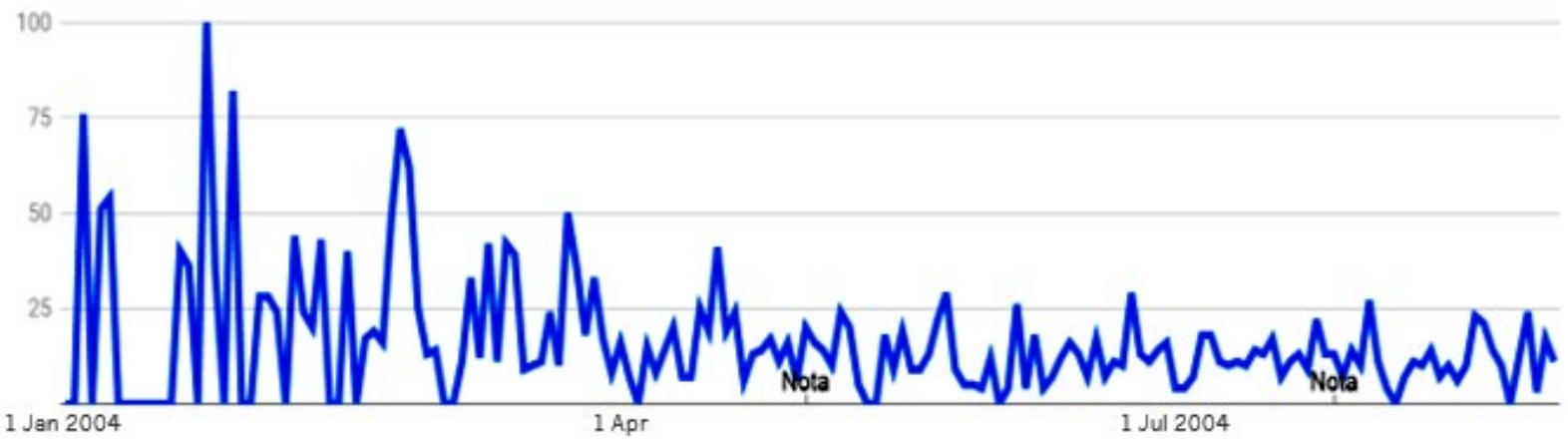

Indeed, if we contrast this evolution with the attention devoted to the subject in the main reference newspapers in Spain, El País and El Mundo, we can see a coincidence in the decreasing and finally stabilized trend in the interest in the subject, much more marked in the case of El Pais. This newspaper has reserved in its digital edition a specific thematic label or "tag" for this issue, which facilitates its monitoring. Figure 4 shows the evolution of the frequency of news items collected in this category.

FIGURE 4

EVOLUTION OF NEWS IN THE "INSTITUTIONAL ADVERTISING” TAG OF EL PAÍS

MONTHLY NEWS WITH THE “INSTITUTIONAL ADVERTISING” TAG

(El país, November 2007 - January 2018)

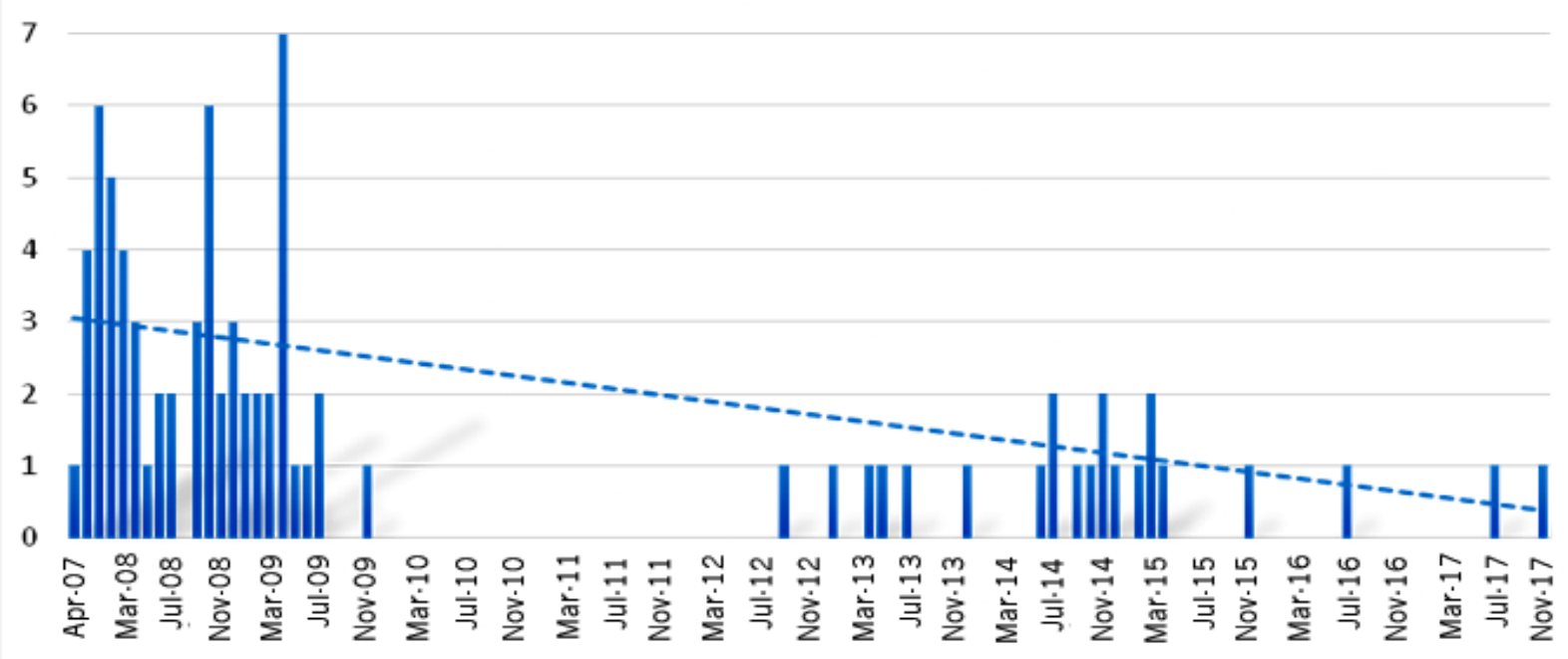

Source: own research.

Data source: Elpais.com 
FIGURE 5

EVOLUTION OF NEWS IN THE "INSTITUTIONAL ADVERTISING" TAG OF EL MUNDO

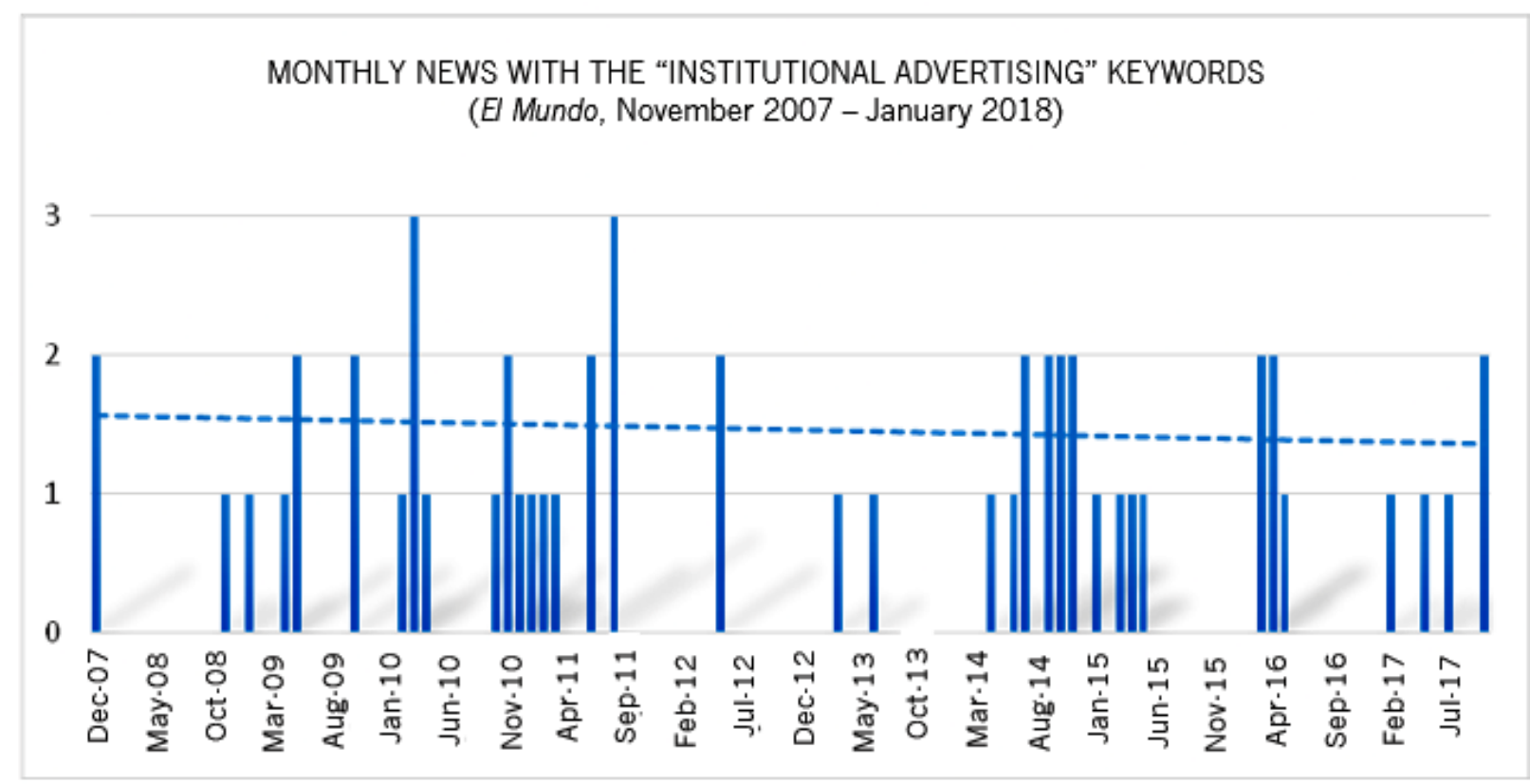

Source: own research

Data source: Elmundo.es

The newspaper El Mundo does not devote any of its thousands of thematic labels specifically to the question of ISC or any synonymous expression that points to this same semantic field ${ }^{5}$. Its editorial criteria consist of marking these news items with the labels corresponding to the parties, politicians and regions mentioned in each news item. But if we use their advanced search engine to track the related search keys and complement it with the advanced search tool for a single domain offered by Google, we get a total of 68 results since November 2002. While this selection may not be exhaustive ${ }^{6}$, it is sufficient to identify the general trend of its evolution over time as well as the thematic sub-areas that constitute journalistic interest within this issue.

In terms of chronological distribution, we find that news coverage over the last decade has been scarce (the average is 8,3 news items per year for El Pais and 5,4 for El Mundo) and that the trend has been markedly downward in El Pais (2,75 news items per year between 2010 and 2017, both included) while in El Mundo it has maintained a more stable frequency. The low frequency of information in comparison to other controversies of public interest, budgetary or on government action, indicates the presence of an informative blind spot that receives less attention than one would expect on the basis of deontological and professional criteria of newsworthiness, or even the existence of a conscious taboo, given the evident conflict of interest that talking about the distribution of public money to the media implies for a large news organization, which in the end acts as privileged devices of social mediation and therefore as opinion makers.

Table 1 summarizes the thematic structure of the news coverage on this issue, identifying as a "general map" the different focuses of interest within the ISC macro-theme and collecting the distribution of the mentioned news corpus in six thematic sub-areas: 1) International (referring to other countries), 2) Regional level (departing from our object of study, which is the ISC at the state level in state newspapers), 3) Content (referring to the content of specific campaigns, not their distribution in the media), 4) Costs (analyzing the amounts invested and their evolution), 5) Judicial (complaints and sentences related to ISC) and 6) Legal (parliamentary or social debates on the regulation of ISC). The categories potentially destined to receive 
news about our focus of interest would be mainly these last three $(4,5$ and 6$)$. This typology will allow us to compare the structure of coverage between the different editorial lines.

The first thing that stands out is the thematic imbalance according to the territorial distribution. While for example El Pais has at times dedicated efforts to denounce the injection of public funds to related media at the regional level, especially in nationalist governments of Convergència $i$ Unió (CiU), the Catalan tripartite, Partido Nacionalista Vasco (PNV) and Bildu in the Basque Country, as well as in traditional strongholds of the Partido Popular such as the Xunta de Galicia, the Valencian Community or Cádiz (practically all the news registered about Andalusia refers to this city when it was governed by that party), this same effort is not perceived at a state level, where no news about this illegitimate use of ISC is registered (despite being a state newspaper) or for the Community of Madrid, where the newspaper has its headquarters, which registers a much smaller number of information in this sense. This observation strengthens the hypothesis of conflict of interest.

The same phenomenon can be observed in El Mundo, which records much more information at the regional level (again with special incidence in the Basque Country and Catalonia) than at the national level or in the Community of Madrid. Most of the information, therefore, is limited to non-State level administrations. This is particularly noteworthy in the case of state newspapers, which have also been eliminating and reducing sections and editorial offices in favor of their national edition due to the economic crisis.

TABLE 1

DISTRIBUTION IN THEMATIC SUB-AREAS OF THE NEWS ABOUT ISC IN EL PAÍS (EP) AND EL MUNDO (EM)

\begin{tabular}{|c|c|c|c|c|c|}
\hline Subtopic & Description & $\begin{array}{l}\text { EP news and } \\
\text { observations }\end{array}$ & $\begin{array}{c}\text { EP } \\
\text { Sum }\end{array}$ & $\begin{array}{l}\text { EM news and } \\
\text { observations }\end{array}$ & \begin{tabular}{|l|} 
EM \\
Sum
\end{tabular} \\
\hline International & News from other countries & $\begin{array}{l}1 \text { in } 2014 \\
1 \text { in } 2016 \\
1 \text { in } 2018 \\
\end{array}$ & 3 & 0 & 0 \\
\hline $\begin{array}{l}\text { Content of } \\
\text { specific } \\
\text { campaigns }\end{array}$ & $\begin{array}{l}\text { Specific campaigns are } \\
\text { announced, demanded or } \\
\text { criticized based on their content } \\
\text { (does not enter into the media } \\
\text { bias of investment) }\end{array}$ & $\begin{array}{l}12 \text { noticias in } 2008, \\
2 \text { in } 2009 \\
1 \text { in } 2017\end{array}$ & 15 & $\begin{array}{l}2 \text { noticias in } \\
2007\end{array}$ & 2 \\
\hline $\begin{array}{l}\text { Costs / } \\
\text { Budget }\end{array}$ & $\begin{array}{l}\text { News about costs, cuts, } \\
\text { evolution of the ISC budget }\end{array}$ & $\begin{array}{l}1 \text { in } 2015 \\
3 \text { in } 2008 \\
2 \text { in } 2009\end{array}$ & 6 & $\begin{array}{l}1 \text { in } 2016 \\
1 \text { in } 2015 \\
2 \text { in } 2012 \\
3 \text { in } 2011 \\
1 \text { in } 2010 \\
1 \text { in } 2009 \\
3 \text { in } 2003 \\
1 \text { in } 2002\end{array}$ & 13 \\
\hline Judicial & $\begin{array}{l}\text { Court rulings, investment bias, } \\
\text { lack of transparency }\end{array}$ & $\begin{array}{l}2 \text { noticias in } 2008 \\
1 \text { in } 2009 \\
1 \text { in } 2017\end{array}$ & 4 & $\begin{array}{l}1 \text { in } 2014 \\
1 \text { in } 2013 \\
1 \text { in } 2004\end{array}$ & 3 \\
\hline $\begin{array}{l}\text { Legal, } \\
\text { regulation. }\end{array}$ & $\begin{array}{l}\text { Proposals or demands for } \\
\text { regulation, parliamentary } \\
\text { debate }\end{array}$ & $\begin{array}{l}4 \text { news in } 2008 \\
\text { (approval of the } \\
\text { respective laws in } \\
\text { Madrid and Galicia) }\end{array}$ & 4 & $\begin{array}{l}1 \text { in } 2016 \\
1 \text { in } 2013 \\
3 \text { in } 2005 \\
1 \text { in } 2004 \\
2 \text { in } 2003\end{array}$ & 8 \\
\hline Regional & Catalonia & 2 news in 2007 & 13 & 3 in 2017 & 10 \\
\hline
\end{tabular}




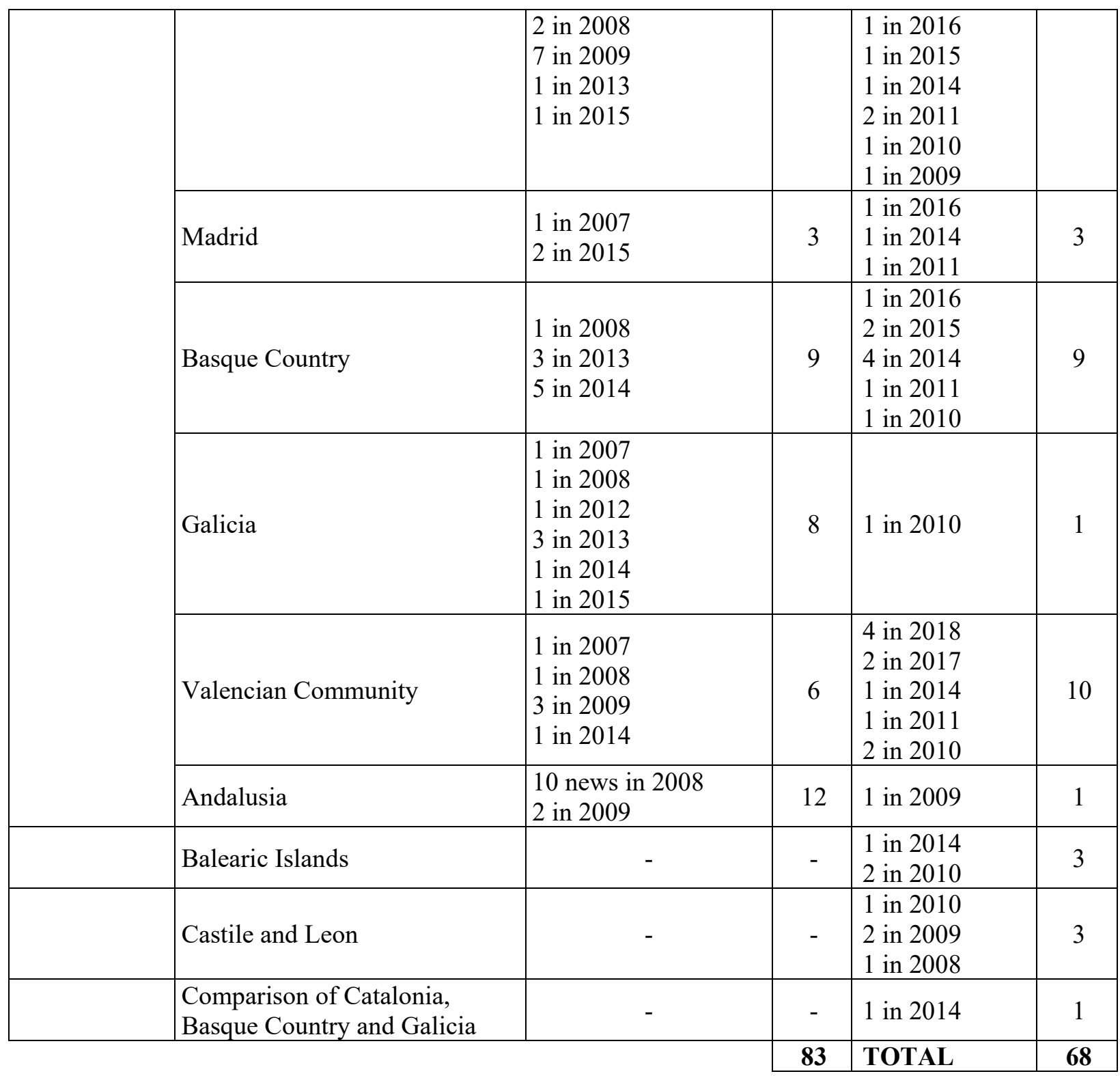

Source: own research

Data sources: Elpais.com and Elmundo.es

In the case of the thematic structure of the coverage carried out by El Pais, both at the national and regional levels, the largest category is that of information or opinion articles aimed at criticizing, demanding or announcing specific campaigns in terms of their content. These are news items that do not focus on the cost and even less on the relationship with the selection criteria of the media receiving the investment, but on the social function of the messages communicated. Secondly, there are news stories about increases or cuts in the budget for ISC, but which systematically ignore the issue of distortion of media competition. A total of 14 candidate news items are recorded to deal with the subject that interests us here (impact of investment on the media market at the state level), which belong to the categories labeled as Legal, Judicial and Budgetary. Of all of them, only two have been produced in the last eight years:

Justice forces Defense to disclose its spending on institutional advertising (24/11/2017)

Economy spends two million to advertise its "intense effort" $(24 / 03 / 2015)$ 
The first one reports on the ruling that requires the Ministry of Defense to respond to a citizen's request to publish data on the ISC investment of eight ministries between 2012 and 2015. Although indirectly, the news effectively constitutes an exception that implicitly alludes to the focus of interest studied. The second one is limited to denouncing the "self-publicity" of the Ministry of Economy without mentioning possible bias in its distribution to the media. A detailed review of the corpus of news items has not detected any that make direct reference to this issue, thus verifying the existence of the journalistic taboo. Repeating this process for the El Mundo newspaper corpus, we found parallel results. Even in the information in which they de facto incursion into the subject, they ultimately avoid directly addressing the question of influence on competition between media at the state level. Two good examples are these news items:

Competition investigates large Spanish advertising companies for agreeing prices $(30 / 05 / 2016)$

Competition initiates proceedings against five media agencies that shared out the State's contracts - (13/09/2016)

Although they de facto deal directly with the issue of allocation of public funds to media, they limit their analysis to contracting agencies without ever mentioning the final allocation to media and the possible bias for their competition. This dynamic is repeated for all the news found in both newspapers.

It is convenient to analyze other related thematic labels, although not synonymous, that could include the information we are looking for. Having evaluated all the news of the tag "Transparency" in El País since January 2014, the electoral year in which new political forces burst in and took advantage of the erosion of the two-party system (Podemos and Ciudadanos), none of them alludes to the issue in question. They basically deal with the transparency of the parties, the actions of the Transparency Council, the assets and income of public officials or the Royal House, or official information on public budgets, but none of them refer to the transparency of public spending on ISC.

The mentioned tag does not exist in the newspaper El Mundo, which however has, as does El País, a specific one on "media". It does not offer different results, however. Of the almost 30,000 news items collected by this category in the last three decades for El Pais, only three of them contain the expression "institutional advertising" and none of them have the perspective we are looking for. Nor do we find any among those shown by the newspaper El Mundo for that label.

In conclusion, if the irregularities related to ISC involve both the political power that distributes it and the media that receive it, the journalistic coverage in the newspapers of reference hides this second involved agent, putting the focus (and in a very sporadic and limited way) only on the first one. In this way, the media exclude themselves from a controversy that directly affects them, which reinforces the hypothesis of a conscious taboo by virtue of a conflict of interest.

Since several news items analyzed denounce excessive expenditures on ISC, or include proposals from parties to regulate such distribution, the possible biased distribution should be interpreted as underlying or implicit, but practically none openly and explicitly discusses it in the same way that, as we will see, the digital native press has done.

\section{COVERAGE IN THE "DIGITAL NATIVE" PRESS}

In the digital newspapers that appeared on the Internet without having a paper edition, and especially in those born in the post-economic crisis and even post-15M, the treatment of this issue is very different. We will study the case of two media such as eldiario.es and infolibre.es, with a progressive editorial line and a business structure specifically designed to guarantee independence, which offer a "clear example of journalism carried out by journalists who defend their profession and aspire to buy their freedom" (Rubio Jordán 2014).

From 2013 to 2017 (included) eldiario.es has published a total of 80 news items related to this issue: an average of 16 news items per year, almost twice as many as El País or three times as many as El Mundo. It also shows an increasing rather than decreasing trend (Figure 6), with 2017 being the year in which it has 
published the most news. But the contrast with the paper press is not only quantitative, it is mainly qualitative.

FIGURE 6

EVOLUTION OF NEWS FROM THE "INSTITUTIONAL ADVERTISING" TAG IN ELDIARIO.ES

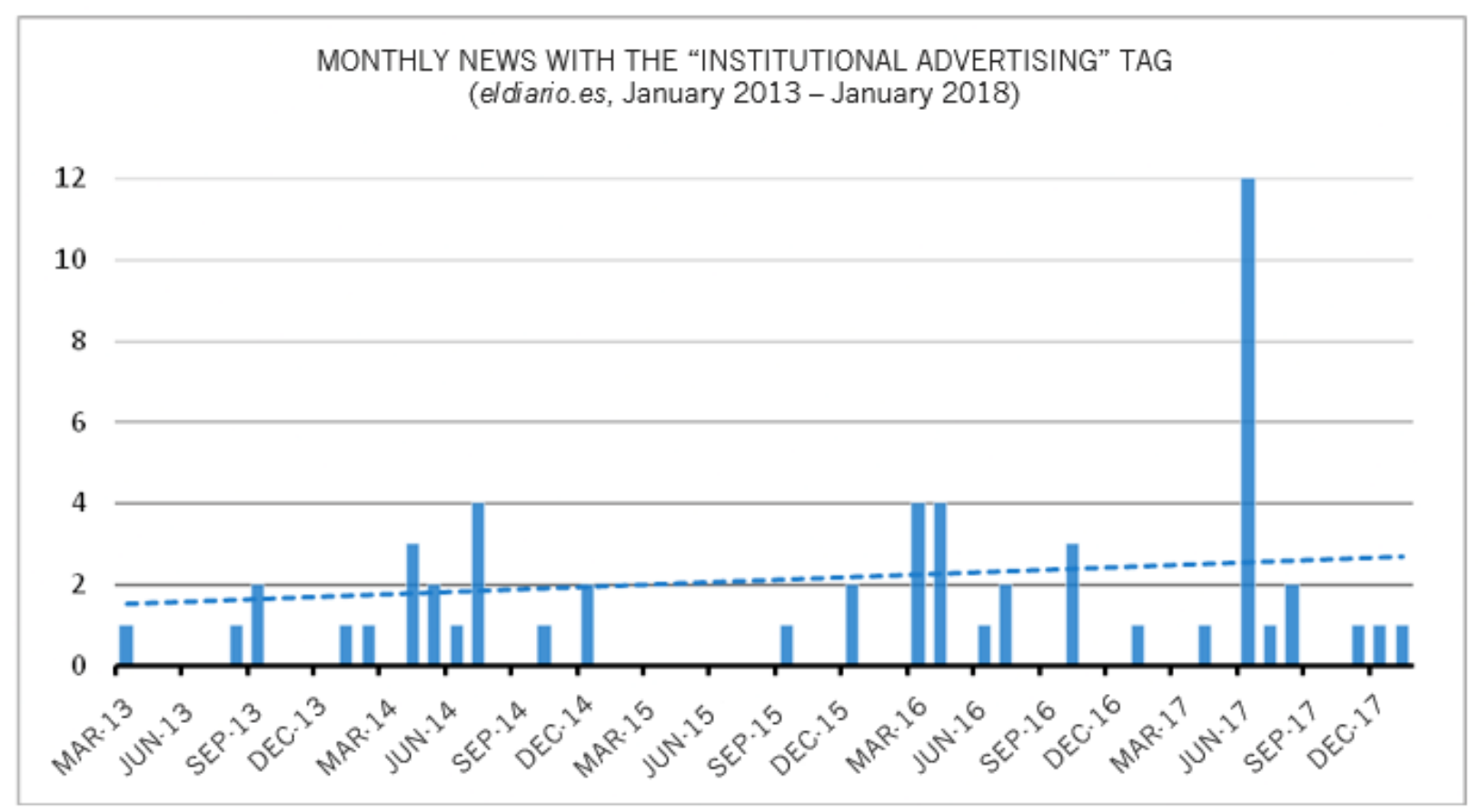

Source: own research

Data source: Elpais.com and Elmundo.es

The impact of ISC on the market is not only not a taboo for eldiario.es, but is the main focus of its coverage of the topic, as evidenced by a content analysis that contrasts the tables of headlines of the "Institutional Advertising" tag in eldiario.es and El Pais, or the table of lexical lemmatized frequencies (Álvarez Peralta 2015, p. 197-208) constructed from the words used in those headlines. While the characteristic differential term (the first one different from those shared by both lexical universes) of the coverage of eldiario.es is "media", in El País it is "campaign" (cf. Table 2). This is consistent with each newspaper's attention to the effect of ISC on the media and on the electoral "self-publicity" of the parties, respectively.

A detailed analysis of cases reveals how effectively eldiario.es has focused on denouncing the adulteration of the media market, which is why it uses terms such as media, money, euros, distribution, web or similar, which occupy prominent places in its table of lexical frequencies, while the second has specialized in denouncing illegitimate campaigns during election time, which is why its characteristic keywords (i.e. with high frequency and in contrast to the previous corpus) are campaign, electoral, election, pre-campaign, propaganda or vote. The detailed qualitative analysis of the news confirms these observations. 
TABLE 2

LEXICAL FREQUENCY TABLES OF THE HEADLINES ABOUT ISC IN EL PAÍS, ELDIARIO.ES AND INFOLIBRE.ES

\begin{tabular}{|c|c|c|c|c|c|}
\hline \multicolumn{2}{|c|}{ El País $\quad(\mathrm{F}>2)$} & \multicolumn{2}{|c|}{ eldiario.es $\quad(\mathrm{F}>3)$} & \multicolumn{2}{|c|}{ infoLibre.es $(\mathrm{F}>2)$} \\
\hline $\begin{array}{ll}32 & \text { advertising } \\
15 & \text { campaign } \\
13 & \text { Government } \\
9 & \text { institutional } \\
9 & \text { millions } \\
8 & \text { Xunta } \\
7 & \text { electoral } \\
7 & \text { law } \\
6 & \text { elections } \\
6 & \text { propaganda } \\
6 & \text { euros } \\
5 & \text { City Hall } \\
5 & \text { official } \\
4 & \text { Barcelona } \\
3 & \text { pre-campaign } \\
3 & \text { bipartite } \\
3 & \text { opposition } \\
\end{array}$ & $\begin{array}{|ll|}3 & \text { public } \\
3 & \text { critic } \\
3 & \text { Teófila } \\
3 & \text { Mayor } \\
3 & \text { Consell } \\
3 & \text { Fomento } \\
3 & \text { distribution } \\
3 & \text { costs } \\
3 & \text { Madrid } \\
3 & \text { Cádiz } \\
3 & \text { spends } \\
3 & \text { vote } \\
3 & \text { CAC } \\
3 & \text { CiU } \\
& \\
\end{array}$ & 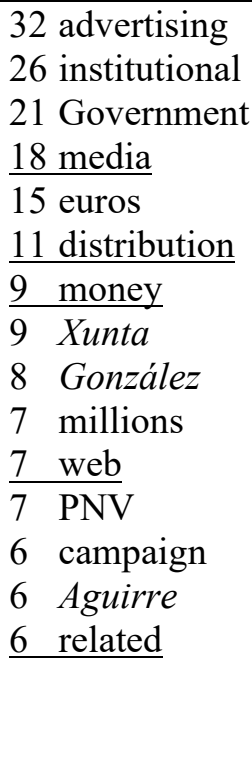 & \begin{tabular}{|ll}
5 & advertisements \\
5 & Madrid \\
5 & Feijóo \\
5 & Canal \\
5 & Razón \\
4 & Transparency \\
4 & audience \\
4 & Urkullu \\
4 & Metro \\
4 & slogan \\
4 & Law
\end{tabular} & $\begin{array}{ll}18 & \text { advertising } \\
11 & \text { millions } \\
10 & \text { euros } \\
9 & \text { media } \\
7 & \text { institutional } \\
5 & \text { paid } \\
4 & \text { Castilla-La } \\
& \text { Mancha } \\
4 & \text { Government } \\
4 & \text { campaigns } \\
4 & \text { Cospedal } \\
4 & \text { Madrid } \\
4 & \text { beneficiaries } \\
4 & \text { years }\end{array}$ & \begin{tabular}{|l}
3 communication \\
3 newspapers \\
3 know \\
3 million \\
3 Méndez \\
3 group \\
$\underline{3 \text { Pozo }}$ \\
\end{tabular} \\
\hline
\end{tabular}

Source: own research

Data sources: Elpais.com, eldiario.es and infoLibre.es

In addition, eldiario.es includes in high positions in its frequency table some specific commercial brands related to market adulteration scandals and prevarication in the distribution of funds, such as Canal de Madrid, Metro de Madrid and the newspaper La Razón. This type of headline relating media "doping" with specific commercial brands is a practice absent in the paper newspapers, both in El Mundo and El Pais, which do not record any similar headline in their entire history. Some headlines that exemplify the emphasis that this editorial line makes on this approach are those shown in Table 3.

Despite having fewer years of existence (since September 2012) and far fewer resources or turnover than previous newspapers, the digital newsroom of eldiario.es has produced a much greater density of information about the adulteration of the information market. This is probably due precisely to the fact that, due to pragmatic, deontological or political factors, it has not entered into biased distributions so that not only there is no conflict of interests, but the conflict operates in the opposite direction: that there is a direct commercial interest in the distribution being transparent and objective in order to improve its competitive options. We will not know this until the institutional media plans are published in detail, but this is clear from the intervention of the director of this media in the Constitutional Commission of Congress on 10 April $2014^{7}$, or in an editorial entitled "Buying media and journalists with public money" , on June 5, 2017:

Unlike what happens in most European countries, the data on the distribution of institutional advertising is secret in almost all Spanish administrations. With those funds, some politicians buy journalists, covers, editorials, columnists, talk shows... Behind the opacity in this advertising distribution hides the main lever to control the press: a powerful tool for propaganda and censorship. (...) In many cases, advertising does not depend on your audience, but on how you behave with the politician in charge, who decides arbitrarily and uses everyone's money to feed his own network of clients... 


\section{TABLE 3 \\ NEWS IN ELDIARIO.ES THAT MENTION THE DISTORTION OF THE INFORMATION MARKET VIA ISC}

A ruling forces the Ministry of Health to reveal how much money it gives out in advertising to each media $-03 / 13 / 2018$

The Government of the Canary Islands hides the name of the media in which it announces - 12/10/2017

Government loses first recourse to keep media advertising secret - 11/24/2017

This is how the Valencian Government distributes institutional advertising among the media $08 / 05 / 2017$

Godó and Zeta share $44.5 \%$ of the institutional publicity of the Generalitat $-06 / 08 / 2017$

Subsidized Journalists - 06/07/2017

The Tax Office favors Alfonso Rojo's website with institutional advertising money - 06/06/2017

Aguirre and González gave 240,000 euros between the Canal and Metro to El Pulso, a website without an audience $-06 / 06 / 2017$

La Razón took $60 \%$ of the advertisements in the press with the Aguirre and González Governments from the Metro - 06/05/2017

Buying media and journalists with public money $-06 / 05 / 2017$

The PSOE requests the appearance of the Vice President for the concealment of the distribution of institutional publicity - 06/05/2017

Journalists' organizations defile the government's maneuvers to conceal how it distributes advertising $06 / 05 / 2017$

The Isabel II channel distributed 1.88 million to La Razón in institutional advertising in ten years $04 / 20 / 2017$

Aguirre and Gonzalez rewarded the related media in the distribution of Healthcare advertising $03 / 18 / 2017$

Compromís asks the government why it "benefits media close to Rajoy - 10/14/2016

Losantos charges against the newspaper.es for revealing that it is one of the most benefited by institutional advertising - 10/14/2016

The Government benefits La Razón, ABC and Jimenez Losantos' website in the distribution of ads $10 / 13 / 2016$

The Isabel II channel paid 141,031 euros in ads to a website without an audience - 05/27/2016

Gallardos distributed eight million euros in advertising among related media during the golden years $03 / 29 / 2016$

This is how Botella benefited the PP-related media with the distribution of the City Council's publicity $-03 / 28 / 2016$

Defense insists on placing the same ads in the newsppers regardless of the audience $-06 / 21 / 2014$

Defense will distribute institutional advertising in the press regardless of the number of readers $02 / 18 / 2014$

La Razón and $\mathrm{ABC}$, the newspapers that received the most money from a campaign against gender violence - 09/05/2013

Publishers call for institutional advertising to be subject to the Transparency Law $-05 / 21 / 2013$

Source: own research

Data sources: eldiario.es (from 09/18/2012 until 04/18/2018)

Indeed, the insistence of this editorial line on a phenomenon systematically hidden in the previous ones strengthens the initial hypothesis of conflict of interest.

As for the coverage made by infolibre.es (born in March 2013), a media whose journalistic production is lower, in line with its income and budget, not only than that of the large paper media, but also that of eldiario.es. However, it is not necessary to make an extensive argument to conclude that the coverage made 
by infolibre.es about this controversy is in a parallel editorial line to the one adopted by eldiario.es. As $E l$ Mundo did, infoLibre does not devote a specific tag to this issue, but places the related news in tags such as "Media", "Advertising Campaigns" and "Transparency", or in those referring to each political actor involved. Applying an identical recovery criterion to that used in the case of El Mundo, we successfully recovered a corpus of headlines that show an editorial line that not only accommodates, but also gives priority to denouncing the ISC's interference in the information market.

\section{TABLE 4 \\ HEADLINES IN INFOLIBRE.ES THAT MENTION THE DISTORTION OF THE INFORMATION MARKET VIA ISC}

- This is how the Government of Lambán distributed the million euros it spent on institutional advertising in $2017-02 / 22 / 2018$

- The businessman who admitted the legal financing of the PP declares that he was compensated with Aguirre's 'advertising tax' - 01/04/2018

- Camarena cracks down on journalistic corruption - 08/13/2017

- European report warns of the influence of public institutions on the Spanish media - 06/25/2017

- Media system in Spain: ten reforms pending - 04/19/2017

- The publisher of 'El País' was the most benefited group in the distribution of advertising of the Junta de Andalusia since $2011-02 / 23 / 2017$

- Cifuentes allocates 20 million to institutional advertising for the next two years - 07/08/2016

- The bishops' media were the most benefited in the distribution of publicity for Cospedal - 06/14/2016

- Aguirre and Gonzalez spent since 2006 almost 55 million euros of Canal de Isabel II in media advertising - 05/25/2016

- Cospedal paid one million to advertise Castilla-La Mancha on Navarra's Méndez Pozo TV 05/06/2016

- Cospedal paid 38 million euros in advertising to the media while it governed Castilla-La Mancha 05/05/2016

- Madrid City Council paid 20.3 million in advertising to media from 2013 to 2015 - 03/25/2016

- The Court of Auditors sees irregularities in institutional advertising between 2010 and 2012 05/06/2015

- Madrid spends 10.6 million euros on institutional advertising in the pre-election period - 03/15/2015

- Institutional advertising within the limits of the law - 10/24/2014

- Union, Progress and Democracy denounces the Basque Government for paying for information with public money - 07/14/2014

- The Ministry of Finance will spend 77 million on advertising - 04/01/2014

- The Government will spend 2.5 million to 'sell' its labor reform - 11/30/2013

- Bad times for community journalism - 03/17/2013

Source: own research

Data sources: infoLibre.es (from 03/07/2013 until 04/18/2018)

In the frequency table of its lexical cloud (cf. Table 4), terms related to the market bias (media, beneficiaries, newspapers, Pozo) also stand out before the lexical axis related to the electoral self-publicity (campaign, pre-campaign, vote, elections), so its thematic structure is closer to that of eldiario.es than to that of El País.

The differences that we have been establishing between the coverage of the traditional press and that of the new digital ones are once again evident when practicing a series of multiple searches (in tags, advanced search in Google, social networks and each media's own search engine) tracking the specific cases 
of biased distribution of ISC favoring related media that have circulated in the digital public sphere, which have become known thanks to parliamentary questions or leaks from the institutions (cf. Table 5).

TABLE 5

\section{COMPARATIVE COVERAGE OF CASES OF ILLEGITIMATE USE OF THE ISC TO} DISTORT COMPETITION IN THE INFORMATION MARKET

\begin{tabular}{|l|c|c|c|c|}
\hline & eldiario.es & El País & infoLibre.es & El Mundo \\
\hline Ministerio de Sanidad Case & Yes & Not found & Not found & Not found \\
\hline Alfonso Rojo and Periodista Digital Case & Yes & Not found & Yes & Not found \\
\hline El Pulso Case & Yes & Not found & Not found & Not found \\
\hline $\begin{array}{l}\text { Elizabeth II Channel, } \\
\text { La Razón and other media }\end{array}$ & Yes & Not found & Yes & Not found \\
\hline Arpegio Case & Yes & Yes & Yes & Yes \\
\hline Botella Case & Yes & Not found & Yes & Not found \\
\hline Denunciation of Compromís & Yes & No & Not found & Not found \\
\hline
\end{tabular}

Sources: own research

\section{CONCLUSIONS}

In this study we have confirmed the almost total absence of academic research in Spain on the distortion of free competition in the information market that the possible biased distribution of ISC to related media implies, which some business people, journalists, academics and politicians have denounced. It is therefore desirable to increase the dedication of research efforts and resources to this issue.

Likewise, we have registered a markedly unequal attention in different editorial lines, confirming a very significant scarcity of this controversy in the traditional press of reference, which contrasts with the attention paid to the same topic by the new digital newspapers analyzed. Furthermore, both in the case of academic research and news coverage in the traditional press, the attention is focused on the evolution of ISC budgets, discursive or content analysis of campaigns, debates about its legislation and even its influence as an economic factor for various markets, but with little explicit attention to the distortion of free competition that it potentially represents for the information market.

Our observations suggest that a transition could be taking place from a logic of direct self-praise by the political power (journalistically referred to as "self-publicity") that implies a misuse of ISC to publicize the administration's successes in periods close to the elections (Cortés González 2011, p. 19), towards another logic that we could call "delegated self-praise", a sort of indirect self-praise in which the budgets for ISC would be injected into the market in a biased manner with relative independence of its contents, contracting greater quantities with media whose editorial line is akin to the political tendency of the party that promotes it.

Despite the fact that the law requires administrations to publish their media plans, in practice the distribution of ISC among media remains opaque with very few exceptions, because each administration generally contracts with a very small number of private media agencies that refuse to publish the detail of their media plan. Our recommendation in this regard is the development of regulations that require the publication of these plans in detail in order to prevent and avoid any bias that could be distorting free competition in the information market based on political affinities.

\section{ACKNOWLEDGEMENT}

Translated \& Edited by American Publishing Services (https://americanpublishingservices.com/). 


\section{ENDNOTES}

1. Cf. http://www.consejodetransparencia.es/ct_Home/Actividad/recursos_jurisprudencia/Recursos_AGE /2017/38 publicidadinstitucional.html

2. Cf. http://www.lamoncloa.gob.es/serviciosdeprensa/cpci/Paginas/PlanesEInformes.aspx

3. Cf. https://contratacioncentralizada.gob.es/acuerdos-marco

4. Cf. https://rends.google.es/trends/explore?date=all\&geo=ES\&q="publicidad\%20institucional"

5. The set of keywords used in the advanced search engines of each media and Google has been the following: institutional advertising, official advertising, official campaign, institutional campaign, Law of Advertising and Institutional Communication, LAIC (LPCI in Spanish), propaganda as primary terms, and self-publicity, anti-publicity, media plan, transparency, announcement, investment or media, as secondary terms. The advanced search includes the derivations that share lexeme (plurals, conjugation, noun, etc.) and involve diverse types of combinations (OR, AND, NOT etc.), weightings and limitations by date, site, level of coincidence, etc. The error when retrieving news from the same media through different search engines is in any case less than 1,2 news/year and does not alter the conclusions about its typology, density and focus of interest.

6. It can be assumed that it excludes some news whose main focus is not this topic even if it treats it in a secondary way, although our corpus does not comprise a random sample but the universe or complete census of all the news published in the digital version.

7. Cf. https://www.eldiario.es/politica/Ignacio-Escolar-propone-transparencia-incluya_0_120388899.html

8. Cf. https://www.eldiario.es/escolar/Comprar-medios-periodistas-dinero-publico_6_651344889.html

9. EP and EM treat it as part of the Lezo Case, but do not address the anti-competitive influence of the ISC in the market.

\section{REFERENCES}

Alameda García, D., \& Fernández Blanco, E. (2002). Aproximación conceptual a la publicidad institucional (Conceptual approach to institutional advertising). Sphera publica: Revista De Ciencias Sociales y de la Comunicación, (2), 159-174. ISSN 1180-9210

Álvarez-Peralta, M. (2014). La crisis estructural del periodismo en España (The structural crisis of journalism in Spain). El Viejo Topo, (322), 58-64. ISSN 0210-2706

Álvarez-Peralta, M. (2015). La crisis en portada: Representaciones de la crisis económica en la prensa española de referencia (2008-2012) (The crisis on the front page: Representations of the economic crisis in the Spanish press of reference (2008-2012)). Universidad Complutense de Madrid.

Canel, M.J., \& Sanders, K. (2010). Para estudiar la comunicación de los gobiernos. Un análisis del estado de la cuestión (To study government communication. An analysis of the state of affairs). Comunicación y Sociedad, 23(1), 7-48. ISSN 0214-0039

Collantes, F.X.R. (2009). El Estado es el producto. Publicidad institucional, rutinas discursivas e ideología de Estado (The State is the product. Institutional advertising, discursive routines and State ideology). Questiones Publicitarias, O(1), 268-293. ISSN 1988-8732

Cortés González, A. (2008). Conceptualización de la publicidad institucional en su dimensión socializadora y educativa. (Conceptualization of institutional advertising in its socializing and educational dimensión). Espacios Públicos, 11(22), 226-237. ISSN 1665-8140

Cortés González, A. (2011). La publicidad institucional en España. Una década en perspectiva. (Institutional advertising in Spain. A decade in perspective.). Razón y Palabra, 16(75). ISSN $1605-4806$

Cuesta, U., Ugarte, A., Gaspar, S., \& Menéndez, T. (2011). Comunicación social institucional y salud: El caso de Madrid Salud del Ayuntamiento de Madrid. (Institutional social communication and health: The case of Madrid Salud del Ayuntamiento de Madrid). II Congreso Internacional Ciudades Creativas.

Díaz-Nosty, B. (2011). Libro negro del periodismo en España (Black book of journalism in Spain). Madrid: Asociación de la Prensa de Madrid. ISBN 978-84-87641-47-3 
Escolar, A. (2014). Publicidad institucional: Aún pesebre y trabuco. (Institutional advertising: Still crib and blunderbuss.). Cuadernos de Periodistas, 28, 14-19. ISSN 1989-3876

Feliu Albaladejo, Á., \& Feliu García, E. (2012). Publicidad institucional en la Comunidad Valenciana: La Generalitat como anunciante (Institutional advertising in the Valencian Community: The Generalitat as an advertiser). Fragua. ISBN 978-84-7074-498-3

Feliu García, E., \& Feliu Albaladejo, Á. (2011). La publicitat institucional a Catalunya. (Institutional advertising in Catalonia). Comunicació: Revista de Recerca i d'Anàlisi, 28(2), 47-67. ISSN 2014-0304

Feliu García, E., \& Feliu Albaladejo, Á. (2016). Publicidad institucional y cambio de gobierno (Institutional advertising and change of government). Actas del I Congreso Internacional Comunicación y Pensamiento, pp. 602-621. Sevilla: Egregius. ISBN 978-84-945243-2-5

Feliu-Albaladejo, Á. (2009). Los ámbitos de la publicidad institucional. (The areas of institutional advertising). Comunicación.Memoria, Historia, Modelos. Edipo, pp. 428-436.

Feliu-Albaladejo, Á. (2011). La publicidad institucional en la arena parlamentaria española. (Institutional advertising in the Spanish parliamentary arena). Revista Latina de Comunicación Social, (66), 128.

Fernández Alonso, I., \& Blasco Gil, J.J. (2014). Press subsidy policies in Spain in the context of financial crisis (2008-2012): An analysis of the Catalan case. European Journal of Communication, 29(2), 171-187. ISSN 0267-3231

Fernández Alonso, I., Guimerà I Orts, J.À., \& Fernández Viso, A. (2012). Impacto de la crisis económica en las políticas de comunicación de la Generalitat de Cataluña (2011). (Impact of the economic crisis on the communication policies of the Generalitat of Catalonia (2011)). Derecom, (18), 8. ISSN 1988-2629

Fernández Poyatos, M.D., \& Feliu García, E. (2012). La Publicidad Institucional de la Junta de Andalucía. (The Institutional Advertising of the Junta de Andalucía). Pensar la Publicidad, 6(1), 115-138. ISSN 1887-8598

Gálvez Muñoz, L.A. (2011). La Ley de Publicidad y Comunicación Institucional y su aplicación en período electoral. (The Law of Publicity and Institutional Communication and its application in the electoral period). Revista Española de Derecho Constitucional, (92), 171-193. ISSN 0211-5743

García Llorente, J. (2015). El Gobierno de España como anunciante publicitario: La publicidad institucional y comercial de la Administración General del Estado (2006-2013). (The Spanish Government as an advertiser: Institutional and commercial advertising of the General State Administration (2006-2013)). Razón y Palabra, 19(89).

García López, M. (2001). Publicidad institucional: El Estado anunciante (Institutional advertising: The advertiser state). Málaga: Servicio de Publicaciones de la Universidad de Málaga. ISBN 978-847496-908-5

García López, M. (2012). Publicidad institucional. Una necesaria reflexión a contracorriente. (Institutional advertising. A necessary rethinking). Revista de Estudios para el Desarrollo Social de la Comunicación - Redes.com, 1(4), 291-306. ISSN 1696-2079

Gómez, D., \& Gómez, P. (2017, March 3). Publicidad institucional: ¿Compra de voluntades o fomento de la pluralidad? (Institutional advertising: Buying wills or promoting plurality?). Revista Digital ctxt.es - Contexto y Acción. Madrid.

Gómez, L., \& Aubia, L. (2009). Las estrategias persuasivas de la Administración española. (The persuasive strategies of the Spanish Administration). Questiones Publicitarias, 0(1), 207-226. ISSN 1988-8732

Guerrero Serón, C.A. (2009). La publicidad institucional durante el primer gobierno Zapatero (2005-06): Elementos formales y estrategias de comunicación. (Institutional advertising during the first Zapatero government (2005-06): Formal elements and communication strategies). Questiones Publicitarias, O(1), 33-136. ISSN 1988-8732 
Martínez Pastor, E. (2016). Estado de la cuestión de la Publicidad Institucional en España (2006-2012). (State of Institutional Advertising in Spain (2006-2012)). Poliantea, 11(21), 105-128. ISSN 2145-3101

Martínez Pastor, E., \& Vizcaíno-Laorga, R. (2008). Publicidad institucional como fenómeno integrador ante la inmigración en España: Régimen jurídico. (Institutional advertising as an integrating phenomenon in the face of immigration in Spain: Legal regime). Revista Latina de Comunicación Social, (63), 91-98. ISSN 1138-5820

Papí-Gálvez, N., \& Orbea Mira, J. (2015). La comunicación institucional con fines políticos: El caso de las campañas de igualdad de género. (Institutional communication for political purposes: The case of gender equality campaigns). Anàlisi: Quaderns de Comunicació I Cultura, (52), 47-62. ISSN 0211-2175

Pineda, A., \& Rey, J. (2009). Propaganda y publicidad institucional: Algunas consideraciones teóricas. (Advertising and institutional publicity: Some theoretical considerations). Questiones Publicitarias, O(1), 9-32. ISSN 1988-8732

Ramos Serrano, M., Garrido Lora, M., \& Rodríguez Centeno, J.C. (2009). Análisis comparativo de la publicidad institucional en España-objetivos y cualidades discursivas. (Comparative analysis of institutional advertising in Spain-objectives and discursive qualities). Questiones Publicitarias, O(1), 227-245. ISSN 1988-8732

Rey, J., Ruiz Collantes, F.X., Pineda Cacheco, A., \& Pérez, Ó. (2009). Introducción monográfica sobre Publicidad Institucional. (Monographic introduction on Institutional Advertising). Questiones Publicitarias, O(1). ISSN 1988-8732

Rodríguez López, M., \& Robles Álvarez, D. (2016). La Publicidad Institucional en España: Análisis de las campañas contra la Violencia De Género del Gobierno (2006-2015) (Institutional Advertising in Spain: Analysis of the Government's campaigns against Gender Violence (2006-2015)). Vivat Academia, 19(134), 86-108. ISSN 1575-2844

Rubio Jordán, A.V. (2014). La aparición de InfoLibre y eldiario.es para la defensa de un periodismo más democrático y participativo. (The appearance of InfoLibre and eldiario.es for the defense of a more democratic and participatory journalism). Historia y Comunicación Social, 19. ISSN 19883056

Ruiz Collantes, F.X., Pujadas, E., Ferrés, J., Obradors, M., Pérez, O., \& Casals, A. (2009). La construcción de la imagen pública de los organismos del Estado y la ciudadanía a través de las narraciones de la publicidad institucional televisiva. (The construction of the public image of State agencies and citizens through the narratives of institutional television advertising). Questiones publicitarias, O(1), 137-206. ISSN 1988-8732

Salaverría, R., \& Gómez Baceiredo, B. (2018). Media Landscapes. European Journalism Centre.

Segura-García, R. (2015). Evolución y efectividad de los spots de la DGT. (Evolution and effectiveness of DGT spots). Opción, 31(3). ISSN 1012-1587

Segura-García, R. (2017). Retórica de las emociones en la publicidad. Audiovisual de la DGT: Análisis de los spots de 1962 a 2013 (Rhetoric of emotions in advertising Audiovisual of the DGT: Analysis of the spots from 1962 to 2013). Doctoral thesis in Universidad de Granada. ISBN 97884-9163-368-6

Urbina Fonturbel, R. (2012). Publicidad institucional y retórica de las emociones. Retórica y política: Los discursos de la construcción de la sociedad (Rhetoric and politics: The discourses of the construction of society). Instituto de Estudios Riojanos, pp. 657-670.

Yarwood, D.L., \& Enis, B.J. (1982). Advertising and Publicity Programs in the Executive Branch of the National Government: Hustling or Helping the People? Public Administration Review, 42(1), 37 46. ISSN 0033-3352 